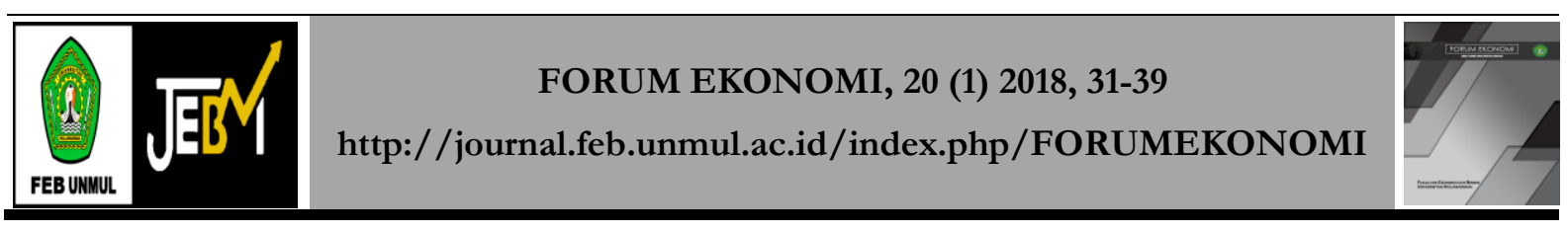

\title{
Pengaruh lingkungan kerja terhadap prestasi kerja pada dinas pertambangan dan energi kabupaten ketapang
}

\author{
Latifah $^{1}$, Nurmalasari ${ }^{2}$ \\ ${ }^{1}$ Jurusan Komputerisasi Akuntansi AMIK BSI, Pontianak. \\ ${ }^{2}$ Jurusan Manajemen Informatika AMIK BSI, Pontianak. \\ Jl. Abdurrahman Saleh No 18 A Pontianak 78124 Pontianak, Kalimantan Barat. \\ ${ }^{1}$ Email: latifah.lat@bsi.ac.id \\ 2Email: Nurmalasari.nrr@bsi.ac.id
}

\begin{abstract}
Abstrak
Tujuan dari penelitian ini adalah untuk mengetahui pengaruh lingkungan kerja terhadap prestasi kerja pada Dinas Pertambangan Dan Energi Kabupaten Ketapang. Metode penelitian yang digunakan adalah metode survei dengan teknik pengumpulan data primer dengan wawancara, kuesioner, studi pustaka dan pengumpulan data sekunder yaitu data sekunder adalah data primer yang telah diolah lebih lanjut dan disajikan baik oleh pihak pengumpul maupun data primer atau oleh pihak lain untuk melengkapi data yang dibutuhkan. pengambilan sampel dengan metode sensus atau complete enumeration dengan sampel sebanyak 32 responden dalam hal ini adalah pegawai Dinas Pertambangan dan Energi Kabupaten Ketapang. teknik analisis data yang digunakan adalah analisis kualitatif dan kuantitatif dengan menggunakan analisis Regresi linear berganda. Berdasarkan hasil Analisis diperoleh angka R sebesar 0,782 sehingga hal ini menunjukkan bahwa terjadi pengaruh yang kuat antara Variabel lingkungan kerja fisik (X1) dan Variabel lingkungan kerja non fisik (X2) dengan Prestasi kerja (Y) dan angka (R2) sebesar 0,611 atau (61,1\%) pada Dinas Pertambangan dan Energi Kabupaten Ketapang hal ini menunjukkan pengaruh Variabel lingkungan kerja fisik (X1) dan Variabel lingkungan kerja non fisik (X2) secara serentak terhadap variabel prestasi kerja (Y) adalah sebesar $61,1 \%$ dan selebihnya dipengaruhi oleh variabel lain.
\end{abstract}

Kata Kunci: Analisis; kepuasan kerja; pegawai

\section{The influence of working environment on work performance in the ketapang mining and energy department}

\begin{abstract}
The purpose of this study was to determine the effect on the performance of the work environment at the Department of Mining and Energy of Ketapang. The method used is survey method with the technique of primary data collection with interviews, questionnaires, literature and collection of secondary data, secondary data is primary data that has been processed further and presented well by the collector and the primary data or by the other party to complete the data required. The sampling or complete enumeration census method with a sample of 32 respondents in this case were employees of the Department of Mines and Energy of Ketapang. Data analysis techniques used are qualitative and quantitative analysis using multiple linear regression analysis. Based on the results of analysis of figures obtained $R$ amounted to 0,782 so that it shows that there is a strong influence between variable physical work environment $(X 1)$ and variable work environment non-physical (X2) with job performance $(Y)$ and numbers $(R 2)$ of 0.611 or $(61,1 \%)$ in the Department of Mines and Energy of Ketapang this shows the influence of the physical work environment variables (XI) and non-physical work environment variables $(X 2)$ simultaneously to work performance variables $(Y)$ was $61.1 \%$ and the rest is affected by other variables.
\end{abstract}

Keywords: Analysis; job satisfaction; employees 


\section{PENDAHULUAN}

Sumber daya manusia merupakan salah satu asset paling berharga yang dimiliki oleh suatu organisasi, karena manusialah yang merupakan satu-satunya sumber daya yang dapat menggerakkan sumber daya lainnya. Dengan demikian, unsur sumber daya manusia merupakan faktor kunci yang harus dipertahankan suatu organisasi sejalan dengan tuntutan yang senantiasa dihadapi organisasi untuk menjawab setiap tantangan yang ada. Oleh karena itu, upaya untuk mempertahankan sumber daya manusia yang berkualitas merupakan langkah utama organisasi. (Arianto, 2013)

Suatu organisasi memiliki beberapa unsur penting salah satunya adalah sumber daya manusia atau tenaga penggerak jalannya organisasi menuju tercapainya tujuan yang telah disepakati terlebih dahulu. Manusia merupakan motor penggerak sumber daya dalam aktifitas dan rutinitas dari sebuah organisasi atau perusahaan. Sebagaimana diketahui sebuah organisasi atau perusahaan, didalamnya terdiri dari berbagai macam individu yang dari berbagai status berupa pendidikan, jabatan dan golongan, pengalaman, jenis kelamin, status perkawinan, tingkat pengeluaran, serta tingkat usia dari masing - masing individu tersebut (Hasibuan, 2009: 21).

Organisasi yang dimaksudkan dalam penelitian ini adalah instansi yang merupakan wadah bagi para sumber daya manusia atau tenaga kerja, baik sebagai pimpinan maupun bawahan. Melihat keberadaan tenaga kerja atau karyawan tersebut maka manajemen perusahaan perlu memperhatikan kepentingan karyawan dan mampu menciptakan suasana kerja yang mendorong peningkatan kepuasan kerjanya. Karyawan dan organisasi sendiri merupakan dua hal yang tidak bisa dipisahkan. Karyawan memegang peranan utama dalam menjalankan roda kehidupan organisasi. Apabila karyawan memiliki produktivitas yang tinggi, maka laju roda pun akan berjalan kencang, yang akirnya akan menghasilkan kinerja dan pencapaian yang baik bagi organisasi.

Tingginya hasil kerja karyawan adalah prestasi yang dicapai oleh karyawan itu pada tingkat tertentu. Prestasi kerja karyawan bukanlah suatu hal yang kebetulan saja, tetapi banyak faktor yang mempengaruhinya. Karena prestasi kerja akan dapat dicapai apabila rencana-rencana kerja yang dibuat dilaksanakan sesuai dengan tugas yang dibebankan pada setiap karyawan yang ada dalam organisasi itu. Oleh karena itu karyawan yang berkualitas adalah karyawan yang melaksanakan pekerjaannya dan mampu memberikan hasil kerja yang baik atau mempunyai prestasi kerja yang tinggi yang dibutuhkan oleh suatu perusahaan, organisasi atau lembaga pemerintah untuk mencapai tujuan. Karena pada dasarnya keberhasilan organisasi secara keseluruhan adalah kontribusi dari hasil kerja karyawannya.

Bagi karyawan, tingkat prestasi kerja yang tinggi dapat memberikan keuntungan tersendiri, seperti meningkatkan gaji, memperluas kesempatan untuk dipromosikan, menurunnya kemungkinan untuk didemosikan, serta membuat ia semakin ahli dan berpengalaman dalam bidang pekerjaannya. Selain itu lingkungan kerja yang nyaman juga dapat mempengaruhi prestasi kerja seseorang, apabila seseorang merasa tempat kerjanya nyaman maka pekerjaan tersebuat akan terselesaikan dengan baik dan prestasi kerja akan meningkat.

Kondisi nyata dari Dinas Pertambangan dan Energi Kabupaten Ketapang adalah tepat berada di depan tempat pembuangan sampah, kondisi fisik kantor yang kurang memadai baik dari segi fisik maupun infrastruktur penunjang seperti AC, komputer, meja dan kursi yang sudah lama, gudang yang berisi peralatan untuk mengukur kegiatan pertambangan berisi zat-zat rentan terbakar dan bau,serta seringnya pegawai turun ke lokasi pertambangan untuk melakukan kegiatan dinas, sehingga rentan terkena radiasi merkuri maupun bahan tambang lainnya. Sedangkan kondisi non fisik sendiri seperti rekan sekerja yang mengaku kurang nya perhatian atasan dalam hal memotivasi karyawan.

Lingkungan kerja bisa dikatakan baik apabila karyawan dapat melakukan pekerjaannya secara optimal dan nyaman (Yugusna, Fathoni, \& Haryono, 2016), Maka dari itu, bisa dikatakan bahwa lingkungan kerja berperan penting terhadap kualitas hasil kinerja karyawan (Potu, 2013).

Jumlah pegawai Dinas Pertambangan dan Energi Kabupaten Ketapang tahun 2015 mengalami penurunan dari tahun sebelum nya karena habis masa kerja (pensiun), namun pada tahun 2016 ditambah satu bidang baru yaitu Geologi dan Sumberdaya mineral dengan jumlah pegawai sebanyak 4 orang, hal ini menyebabkan bertambahnya beban kerja dan kebutuhan untuk mencapai prestasi kerja dengan adanya bidang baru, karena dituntut harus bekerja secara maksimal untuk mengembangakan bidang kerja. Dilihat dari jenis bidang kerja bahwa lebih banyak karyawan yang sering turun 
kelapangan untuk melakukan pengecekan terhadap sumber energi dan kegiatan pertambangan, namun tidak dilengkapi dengan peralatan keselamatan dan kesehatan yang memadai.

Dari latar belakang yang telah diuraikan, penulis ingin mengetahui lebih lanjut apakah ada pengaruh antara lingkungan kerja terhadap prestasi kerja pada Dinas Pertambangan dan energi Kabupaten Ketapang.

\section{Landasan Teori \\ Lingkungan Kerja}

Lingkungan kerja berarti situasi keadaan dimana karyawan melakukan pekerjaan setiap hari. Ada kalanya setiap karyawan mempunyai hak yang sama untuk mendapatkan kenyamanan dalam bekerja. Karena jika karyawan merasa nyaman dengan pekerjaan, maka karyawan akan melakukan pekerjaan dengan sepenuh hati tanpa mengeluh. Contohnya saja kurang AC diruang kerja administrasi, karyawan bekerja menjadi kurang nyaman dan tidak fokus karena kepanasan yang disebabkan tidak ada sirkulasi udara yang masuk (Muayanah, Haryono, \& Wulan, 2017)

Menurut Diah (2016) lingkungan kerja menciptakan kenyamanan tinggi bagi karyawan.Kenyamanan yang tercipta dari lingkungan kerja ini berpengaruh terhadap keseriusan karyawan dalam bekerja sehingga mendorong karyawan untuk bisa bekerja lebih baik karena dukungan lingkungan. Menurut Sarzoska dalam (Nugrah \& Surya, 2016) lingkungan fisik dan lingkungan non fisik merupakan faktor yang mempengaruhi kepuasan selain kompensasi, promosi jabatan serta karakteristik dari pekerjaan yang bersangkutan. Sebab kepuasan kerja karyawan secara langsung bisa meningkat, jika suatu kondisi lingkungan yang baikakan menciptakan keinginan untuk dapat melaksanakan kegiatan secara optimal, sehat, nyaman dan aman. Namun jika kondisi lingkungan yang kurang baik tenaga kerja akan menuntut waktu yang lebih banyak dan tidak mendukung diperolehnya rancangan sistem kerja yang lebih efisien. Pembangunan dan pengembangan berarti perubahan yang dinamis, suatu akseleratif yang diharapkan berdampak positif. Salah satu aspek dalam pembangunan adalah terciptanya lingkungan kerja yang kondusif. Lingkungan kerja adalah faktor-faktor diluar manusia baik fisik mau pun non fisik dalam sesuatu organisasi. (Sofyan, 2013)

Menurut Locke dalam Luthan (2006), kepuasan adalah suatu keadaan emosi senang, gembira atau emosi positif yang berasal dari penilaian pekerjaan atau pengalaman kerja seseorang. Perasaan puas, senang atau gembira akan terlihat dari hasil prestasi kerja yang baik. Sebaliknya jika karyawan merasakan jenuh atau sedih malah akan semakin membuat karyawan merasa terbebani pekerjaan, menjadi malas bekerja, dan dapat menyebabkan tekanan atau streskerja.

Interaksi karyawan dalam lingkungan perusahaan/organisasi/instansi merupakan hal yang tidak dapat dipisahkan yang mana akan menimbulkan tingkat kepuasan kerja karyawan, situasi lingkungan perusahaan dalam melaksanakan tugas dan fungsinya antara karyawan yang satu dengan yang lain tidak terlepas dari interaksi satu sama lainnya demi kelancaran dan keharmonisan kerja. Dengan sarana hubungan yang nyaman akan lebih betah dan senang dalam menyelesaikan tugas. Hubungan antar manusia ( human relation) dalam perusahaan merupakan hal yang penting karena merupakan jembatan antara karyawan dengan sesama karyawan maupun karyawan dengan pimpinan. (Saputro \& Fathoni, 2017)

\section{Prestasi kerja}

Suatu instansi atau perusahaan tentunya memiliki tujuan, tujuan inilah yang membuat instansi atau perusahaan tersebut ada namun terkadang muncul kendala yang membuat tujuan tersebut tidak tercapai. Untuk mencegahnya maka perusahaan harus mendorong karyawan untuk mencapai kinerja dan prestasi yang lebih baik dari waktu ke waktu.Prestasi kerja adalah suatu hasil kerja yang dicapai seseorang dalam melakukan tugastugas yang dibebankan kepadanya yang didasarkan pada kecakapan, pengalaman, dan kesungguhan serta ketepatan waktu. (Judas, 2013).

Untuk mencapai tujuan tersebut dibutuhkan sumber daya manusia yang handal sesuai dengan kapasitas yang dibutuhkan. Oleh karena itu instansi harus memperhatikan pengaruh yang dapat mempengaruhi prestasi kerja karyawan itu diantaranya adalah pengawasan, motivasi dan disiplin kerja (Silalahi, 2014).

prestasi kerja pada dasarnya lebih menekankan pada hasil yang diperoleh dari sebuah pekerjaan sebagai kontribusi instansi/organisasi tempatnya bekerja. Sasaran penilaiannya antara lain kecakapan, kemampuan pelaksanaan tugas yang diberikan, performa dalam melaksanakan tugas, cara membuat 
laporan atas pelaksanakan tugas, dan ketegaran jasmani serta rohani selama bekerja. (Anita, Aziz, \& Yunus, 2013).

Dasar penilaian prestasi kerja adalah uraian pekerjaan dari setiap individu pegawai karena didalam uraian pekerjaan inilah ditetapkan tugas dan tanggung jawab yang akan dilakukan oleh setiap pegawai. Tolak ukur yang dipergunakan untuk mengukur prestasi kerja pegawai adalah standar (Noor, 2013).

Prestasi kerja merupakan suatu hasil kerja yang dicapai seseorang dalam aksanakan tugas-tugas yang dibebankan kepadanya yang didasarkan atas kapan, pengalaman dan kesungguhan serta waktu. Prestasi kerja ini umumnya menyangkut tiga faktor penting yaitu kemampuan dan minat seseorang pekerja, mpuan dan penerimaan atas penjelasan delegasi tugas, serta peran dan motivasi seorang pekerja semakin tinggi ketiga faktor diatas, maka makin besarlah prestasi kerja karyawan bersangkutan (Azikin, 2014)

Kelangsungan hidup suatu organisasi salah satunya tergantung pada prestasi kerja pegawainya dalam melaksanakan pekerjaannya (Utami, 2013)

Setiap perusahaan perlu mengadakan penilaian prestai kerja bagi para karyawannya. Karena ukuran terakhir atas keberhasilan departemen personalia adalah peran karyawan dan pelaksanaan pekerja (wenten, 2013).

\section{METODE}

\section{Bentuk Penelitian}

Penelitian ini menggunakan metode Survey, dengan objek penelitian adalah pegawai pada Dinas Pertambangan dan Energi Kabupaten Ketapang. Penelitian Survey menurut Umar (2013: 34) adalah riset yang diadakan untuk memperoleh fakta-fakta tentang gejala-gejala atas permasalahan yang timbul.

\section{Jenis dan Sumber Data \\ Data Primer}

Data primer adalah data yang didapat dari sumber pertama baik dari individu atau perseorangan seperti hasil wawancara atau hasil pengisisan kuesioner yang biasa dilakukan oleh peneliti. (Umar, 2013:34). Dalam penelitian ini wawancara dan pengisian kuesioner dilakukan dengan cara mendatangi responden yang dalam hal ini adalah pegawai pada Dinas Pertambangan dan Energi Kabupaten Ketapanguntuk diminta tanggapan nya atas pertanyaan-pertanyaan yang diajukan.

Data Sekunder

Kata sekunder berasal dari bahasa inggris "secondary" yang berarti kedua atau bukan secara langsung dari sumbernya melainkan berasal dari pihak lain. Menurut Umar (2013;35) data sekunder adalah data primer yang telah diolah lebih lanjut dan disajikan baik oleh pihak pengumpul maupun data primer atau oleh pihak lain misalnya dalam bentuk tabel-tabel. Data sekunder digunakan untuk diproses lebih lanjut. Dalam penelitian ini yang berupa data sekunder adalah data- data tentang jumlah pegawai baik menurut bidang maupun menurut tingkat pendidikan serta jumlah absensi pegawai.

Teknik Pengumpulan Data

\section{Wawancara}

Wawancara merupakan metode yang digunakan untuk memperoleh data primer. Dalam penelitian ini, wawancara dilakukan dengan komunikasi secara langsung kepada para pegawai Dinas Pertambangan dan Energi Kabupaten Ketapang mengenai pengaruh lingkungan kerja terhadap prestasi kerja pegawai pada Dinas Pertambangan dan Energi Kabupaten Ketapang.

\section{Kuesioner}

Teknik atau suatu cara pengumpulan data dengan menyebarkan daftar pertanyaan tertutup kepada responden. Daftar pertanyaan ini dibagikan kepada pegawai Dinas Pertambangan dan Energi Kabupaten Ketapang yang dijadikan sampel penelitian. Kuesioner berisi pernyataan yang menggambarkan indikator tentang lingkungan kerja dan prestasi kerja pegawai Dinas Pertambangan dan Energi Kabupaten Ketapang. 


\section{Studi Pustaka}

Studi Pustka yaitu mengumpulkan data yang bersumber dari literatur yang berpengaruh dengan penelitian ini seperti buku literatur, jurnal dan informasi dari internet yang ditampilkan pada thesis ini.

\section{Populasi dan Sampel}

Populasi

Populasi menurut Umar (2013:107) adalah jumlah keseluruhan yang mencakup semua anggota yang diteliti. Dalam penelitian ini yang dianggap sebagai populasi adalah seluruh pegawai Dinas Pertambangan dan Energi Kabupaten Ketapang yang berjumlah 32 orang .

Sampel

Sampel menurut Umar (2013:109) adalah suatu bagian yang dapat ditarik dari populasi. Adapun Sampel yang akan digunakan dalam penelitian ini adalah sebagian dari populasi pegawai Dinas Pertambangan dan Energi Kabupaten Ketapang.

Dalam penelitian ini seluruh populasi akan diobeservasi, karena populasi penelitian adalah finit dan cenderung heterogen. Oleh karena itu penelitian ini menggunakan metode Total Sampling, sehingga sample yang digunakan adalah sebanyak 32 orang sesuai dengan jumlah populasi yang ada. Variabel Penelitian

Berikut adalah variabel penelitian yang akan di rangkum dalam tabel berikut:

\section{Tabel 1. Operasional Variabel}

\begin{tabular}{|c|c|c|}
\hline Variabel & Definisi & Indikator \\
\hline $\begin{array}{lll}\text { Lingkungan } & \text { Kerja Fisik } \\
\text { (X1) } & \end{array}$ & $\begin{array}{l}\text { Lingkungan kerja fisik adalah semua } \\
\text { keadaan berbentuk fisik yang } \\
\text { terdapat di sekitar tempat kerja yang } \\
\text { dapat mempengaruhi karyawan baik } \\
\text { secara langsung maupun secara tidak } \\
\text { langsung (Sedarmayanti }(2011: 21) \text { ) }\end{array}$ & $\begin{array}{ll}\text { 1. } & \text { kondisi peralatan kerja (Meja,Kursi } \\
\text { dan Komputer) } & \\
\text { 2. Kondisi Pencahayaan } & \\
\text { 3. Kondisi Temperatur dan Sirkulasi } \\
\text { Udara }\end{array}$ \\
\hline $\begin{array}{lll}\text { Lingkungan } & \text { Kerja } & \text { Non } \\
\text { Fisik (X2) } & & \end{array}$ & $\begin{array}{l}\text { Lingkungan kerja non fisik adalah } \\
\text { semua keadaan yang terjadi yang } \\
\text { berkaitan dengan pengaruh kerja, } \\
\text { baik pengaruh dengan atasan } \\
\text { maupun pengaruh sesama rekan } \\
\text { kerja, ataupun pengaruh dengan } \\
\text { bawahan (Sedarmayanti }(2011: 31) \text { ) }\end{array}$ & $\begin{array}{ll}\text { 1. } & \text { Komunikasi antar rekan sekerja } \\
\text { 2. } & \text { Perlakuan dari rekan sekerja } \\
\text { 3. } & \text { Perlakuan yang adil dari atasan } \\
\text { 4. } & \text { Motivasi materi yang diberikan oleh } \\
\text { atasan } & \\
\text { 5. } & \begin{array}{l}\text { Kerjasama yang baik dan saling } \\
\text { mendukung }\end{array} \\
\end{array}$ \\
\hline Prestasi Kerja (Y) & $\begin{array}{l}\text { kinerja (prestasi kerja) adalah suatu } \\
\text { hasil kerja yang dicapai seseorang } \\
\text { dalam melaksanakan tugas tugas } \\
\text { yang dibebankan kepadanya yang } \\
\text { didasarkan atas kecakapan, } \\
\text { pengalaman dan kesungguhan serta } \\
\text { waktu (Maluyu S.P. Hasibuan } \\
(2009: 34) \text { ) }\end{array}$ & $\begin{array}{ll}\text { 1. } & \text { Kuantitas Kerja } \\
\text { 2. } & \text { Kualitas kerja } \\
\text { 3. } & \text { Keandalan } \\
\text { 4. } & \text { Kehadiran } \\
\text { 5. } & \text { Sikap }\end{array}$ \\
\hline
\end{tabular}

Sumber: Sedarmayanti (2011) dan Hasibuan (2009)

\section{Pengukuran Variabel}

Untuk mengukur variabel penelitian ini, penulis menggunakan Skala Likert yang menurut Kinnear (Umar,2013;98) adalah berpengaruh tentang sikap seseorang terhadap sesuatu. Setiap Variabel mempunyai bobot : Sangat Puas (Skor 5), Puas (Skor 4), Netral (Skor 3), Tidak Puas (Skor 2), Sangat Tidak Puas (Skor 1).

\section{HASIL DAN PEMBAHASAN}

\section{Analisis Regresi Linear Berganda}

Data yang diinput dalam melakukan analisis regresi linear berganda ini, berasal dari hasil skoring terhadap 15 pertanyaan valid yang diajukan kepada 32 responden, dan telah melalui uji validitas dan reliabilitas serta telah di uji tidak ada masalah dalam uji asumsi klasik. Jawaban yang diperoleh dari responden, kemudian dijumlahkan berdasarkan skala Likert $(1,2,3,4,5)$. 
Analisis ini untuk mengetahui arah pengaruh antara variabel independen berpengaruh positif atau negatif dan untuk memprediksi nilai dari variabel dependen denagn variabel dependen apabila nilai variabel independen mengalami kenaikan atau penurunan.

Tabel 2. Analisis Regresi Linear Berganda

\begin{tabular}{|c|c|c|c|c|c|c|}
\hline \multirow[b]{2}{*}{ Model } & & \multicolumn{2}{|c|}{ Unstandardized Coefficients } & \multirow{2}{*}{$\begin{array}{c}\begin{array}{c}\text { Standardized } \\
\text { Coefficients }\end{array} \\
\text { Beta }\end{array}$} & \multirow[b]{2}{*}{$\mathrm{t}$} & \multirow[b]{2}{*}{ Sig. } \\
\hline & & B & Std. Error & & & \\
\hline \multirow[t]{3}{*}{1} & (Constant) & 1.530 & 3.211 & & .477 & .637 \\
\hline & TOTALX1 & .410 & .117 & .442 & 3.495 & .002 \\
\hline & TOTALX2 & .700 & .180 & .491 & 3.887 & .001 \\
\hline
\end{tabular}

a. Dependent Variable: TOTALY

Sumber: Data Olahan, 2015

Hasil analisis data diperoleh model atau fungsi regresi Variabel lingkungan kerja fisik (X1) dan Variabel lingkungan kerja non fisik (X2) sebagai variabel independent maka didapatkan fungsi regresi sebagai berikut:

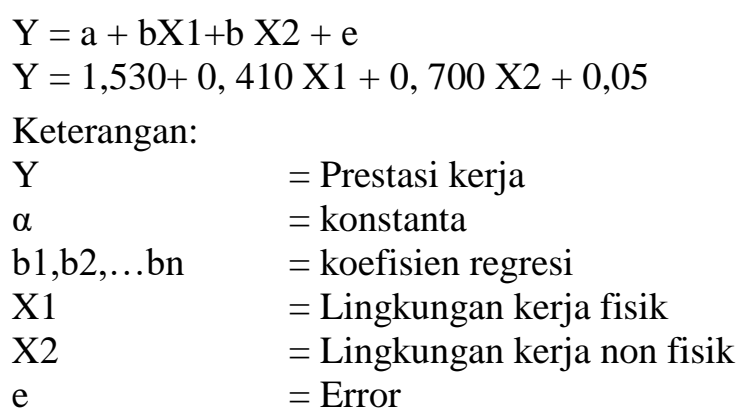

Dari fungsi regresi maka terdapat beberapa kesimpulan yang bisa dikemukakan, yaitu:

Apabila tidak terjadi perubahan terhadap nilai faktor Variabel lingkungan kerja fisik (X1) dan Variabel lingkungan kerja non fisik (X2), maka besarnya prestasi kerja (Y) sebesar 1,530 satu satuan unit.

Apabila faktor Variabel lingkungan kerja fisik (X1) ditingkatkan sebesar satu satuan unit, dan Variabel lingkungan kerja non fisik (X2), konstan, maka besarnya prestasi kerja meningkat sebesar 0 , 410 satu satuan unit.

Apabila faktor penempatan Variabel lingkungan kerja non fisik (X2) meningkat sebesar satu satuan unit dan faktor Variabel lingkungan kerja fisik (X1), konstan, maka besarnya prestasi kerja meningkat sebesar 0,700 satu satuan unit.

\section{Analisis korelasi ganda (R)}

Analisis ini digunakan untuk mengetahui pengaruh antara dua atau lebih variabel independent terhadap variabel dependen secara serentak.

Tabel 3. Analisis Korelasi Ganda

\begin{tabular}{lcccc}
\hline Model & R & R Square & $\begin{array}{c}\text { Adjusted R } \\
\text { Square }\end{array}$ & $\begin{array}{c}\text { Std. Error of the } \\
\text { Estimate }\end{array}$ \\
\hline 1 & $.782^{\text {a }}$ & .611 & .584 & 1.653 \\
\hline a. Predictors: (Constant), TOTALX2, TOTALX1 & \\
Sumber: Data Olahan,2015
\end{tabular}

Berdasarkan hasil Tabel Hasil Analisis Korelasi Ganda di atas, diperoleh angka R sebesar 0,782 sehingga hal ini menunjukkan bahwa terjadi pengaruh yang kuat antara Variabel lingkungan kerja fisik (X1) dan Variabel lingkungan kerja non fisik (X2) dengan Prestasi kerja (Y). 


\section{Analisis Determinasi (R2)}

Analisis determinasi dalam regresi linear berganda digunakan untuk mengetahui persentase sumbangan pengaruh variabel independen $(\mathrm{X} 1, \mathrm{X} 2, \ldots \ldots \mathrm{Xn})$ secara serentak terhadap variabel dependen (Y). Hasil analisis determinasi pada penelitian ini dapat dilihat pada Tabel 3.3 berikut:

Tabel 4. Analisis Determinasi

\begin{tabular}{lrrrr}
\hline Model & R & R Square & $\begin{array}{c}\text { Adjusted R } \\
\text { Square }\end{array}$ & $\begin{array}{c}\text { Std. Error of the } \\
\text { Estimate }\end{array}$ \\
\hline 1 & $.782^{\mathrm{a}}$ & .611 & .584 & 1.653 \\
\hline
\end{tabular}

a. Predictors: (Constant), TOTALX2, TOTALX1

Sumber: Data Olahan,2015

Untuk mengetahui persentase sumbangan pengaruh variabel lingkungan kerja fisik (X1) dan Variabel lingkungan kerja non fisik (X2) secara serentak terhadap variabel prestasi kerja (Y) maka digunakan analisis determinasi (R2). Berdasarkan Tabel Model Summary di atas, diperoleh angka (R2) sebesar 0,611 atau (61,1 \%) pada Dinas Pertambangan dan Energi Kabupaten Ketapang. Hal ini menunjukkan pengaruh Variabel lingkungan kerja fisik (X1) dan Variabel lingkungan kerja non fisik (X2) secara serentak terhadap variabel prestasi kerja (Y) adalah sebesar 61,1\% dan selebihnya dipengaruhi oleh variabel lain yang tidak dimasukkan dalam penelitian ini.

\section{Uji Secara Simultan (Uji F)}

Uji ini digunakan untuk mengetahui apakah variabel independen $(\mathrm{X} 1, \mathrm{X} 2, \ldots \ldots \mathrm{Xn})$ secara bersama-sama berpengaruh secara signifikan terhadap variabel dependen (Y). Kriteria Pengujian:

Ho diterima bila F hitung < F Tabel.

Ho ditolak bila F hitung > F Tabel.

Untuk mengetahui pengaruh variabel independent terhadap variabel dependent secara simultan (bersama-sama) dapat dilakukan melalui uji secara simultan. Uji secara simultan ini yaitu dengan membandingkan antara nilai $\mathrm{F}$ hitung dengan nilai $\mathrm{F}$ Tabel pada tingkat signifikan 0,05 . Nilai $\mathrm{F}$ Tabel 0,05 diperoleh dengan memperhatikan besarnya nilai degree of freedom (df). berikut ini:

Hasil analisis Multiple Regression Uji F ditunjukkan melalui Analisys of Variance pada Tabel

Tabel 5. Hasil Uji Secara Simultan

\begin{tabular}{llrrrrr}
\hline Model & & Sum of Squares & df & Mean Square & F & Sig. \\
\hline 1 & Regression & 124.463 & 2 & 62.231 & 22.771 & $.000^{\mathrm{a}}$ \\
& Residual & 79.256 & 29 & 2.733 & & \\
& Total & 203.719 & 31 & & & \\
\hline
\end{tabular}

a. Predictors: (Constant), TOTALX2, TOTALX1

b. Dependent Variable: TOTALY

Sumber: Data Olahan,2015

Dilihat hasil analisis pada Tabel tersebut diketahui secara simultan atau secara bersama-sama nilai $\mathrm{F}$ hitung sebesar 22.771 sedangkan nilai $\mathrm{F}$ Tabel adalah sebesar 3, 328 sehingga dapat dilihat bahwa nilai F hitung > nilai F Tabel, yaitu $22.771>3,328$ dan dapat disimpulkan bahwa Hipotesis Ho ditolak dan Ha diterima sehingga Prestasi kerja (Y) dipengaruhi secara bersama-sama oleh variabel lingkungan kerja fisik (X1) dan Variabel lingkungan kerja non fisik (X2).

\section{Uji Secara Parsial (Uji t)}

Untuk mengetahui apakah variabel bebas secara parsial berpengaruh signifikan terhadap variabel terikat, maka dilakukan uji t. Untuk mengetahui faktor Variabel lingkungan kerja fisik (X1) dan Variabel lingkungan kerja non fisik (X2) apakah berpengaruh secara parsial (individu) atau tidak terhadap variabel prestasi kerja (Y)dapat diketahui melalui Uji Secara Parsial (Uji t) yang dapat dilihat pada Tabel berikut: 
Tabel 6. Hasil Uji Secara Parsial

\begin{tabular}{|c|c|c|c|c|c|c|}
\hline \multirow[b]{2}{*}{ Mod } & & \multicolumn{2}{|c|}{ Unstandardized Coefficients } & $\begin{array}{l}\text { Standardized } \\
\text { Coefficients }\end{array}$ & \multirow[b]{2}{*}{$\mathrm{t}$} & \multirow[b]{2}{*}{ Sig. } \\
\hline & & B & Std. Error & Beta & & \\
\hline \multirow[t]{3}{*}{1} & (Constant) & 1.530 & 3.211 & & .477 & .637 \\
\hline & TOTALX1 & .410 & .117 & .442 & 3.495 & .002 \\
\hline & TOTALX2 & .700 & .180 & .491 & 3.887 & .001 \\
\hline
\end{tabular}

a. Dependent Variable: TOTALY

Sumber: Data Olahan, 2015

Untuk mengetahui pengaruh secara parsial maka nilai $t$ hitung harus dibandingkan dengan $t$ Tabel. Nilai $\mathrm{t}$ tabel dapat dicari dengan menentukan degree of freedom yaitu (32-2-1) pada uji dua sisi 0,025 sehingga didapat nilai t Tabel adalah $=2,045$.

Ho: Secara parsial tidak ada pengaruh signifikan antara variabel Lingkungan Kerja Fisik (X1) dan variabel Lingkungan Kerja Non Fisik (X2) dengan Prestasi kerja (Y).

Ha: Secara parsial ada pengaruh signifikan antara variabel Lingkungan Kerja Fisik (X1) dan variabel Lingkungan Kerja Non Fisik (X2) dengan Prestasi kerja (Y).

Ho diterima jika $t$ hitung $<\mathrm{t}$ Tabel, dan Ho ditolak jika $t$ hitung $>\mathrm{t}$ Tabel. Selanjutnya dilakukan pengujian terhadap ketiga variabel dalam penelitian ini.

Hasil uji secara parsial antara variabel-variabel lingkungan kerja fisik (X1) dan Variabel lingkungan kerja non fisik (X2) tersebut terhadap Prestasi kerja (Y) adalah sebagai berikut:

Secara parsial nilai t hitung variabel lingkungan kerja fisik (X1), sebesar 3,495 dan t Tabel sebesar 2,045 sehingga $t$ hitung lebih besar dari t Tabel yaitu 3,495 > 2,045. Maka dapat disimpulkan bahwa pada penelitian ini Variabel lingkungan kerja fisik (X1) secara parsial merupakan faktor yang berpengaruh nyata terhadap Prestasi kerja (Y).

Secara parsial nilai t hitung variabel lingkungan kerja non fisik (X2) sebesar 3,887dan t Tabel sebesar 2,045 sehingga thitung lebih besar dari t Tabel yaitu 3,887 > 2,045. Maka dapat disimpulkan bahwa pada penelitian ini variabel lingkungan kerja non fisik (X2) secara parsial juga merupakan faktor yang berpengaruh terhadap prestasi kerja (Y).

\section{SIMPULAN}

Karakteristik responden didominasi oleh responden dengan kelamin laki-laki, pegawai lebih didominasi oleh pegawai yang berumur 40-46 tahun, tingkat pendidikan responden adalah didominasi oleh SMA dengan masa kerja dominan antara 16-20 tahun.

Berdasarkan analisis korelasi ganda, menunjukkan bahwa terdapat hubungan yang kuat antara Variabel lingkungan kerja fisik (X1) dan Variabel lingkungan kerja non fisik (X2) dengan Pretasi kerja (Y), serta berdasarkan analisis Determinasi, pengaruh Variabel lingkungan kerja fisik (X1) dan Variabel lingkungan kerja non fisik (X2) secara serentak terhadap variabel Pretasi kerja (Y) pada Dinas Pertambangan dan Energi Kabupaten Ketapang adalah sebesar 61,1\% dan selebihnya dipengaruhi oleh variabel lain yang tidak dimasukkan dalam penelitian ini.

Berdasarkan uji secara simultan (uji f), dapat disimpulkan bahwa Prestasi kerja (Y) dipengaruhi secara bersama-sama oleh variabel Variabel lingkungan kerja fisik (X1) dan Variabel lingkungan kerja non fisik (X2) dan berdasarkan uji secara parsial (uji t) Variabel lingkungan kerja fisik (X1) danVariabel lingkungan kerja non fisik (X2) secara parsial merupakan faktor yang berpengaruh nyata terhadap Pretasi kerja (Y).

\section{DAFTAR PUSTAKA}

Anita, J., Aziz, N., \& Yunus, M. (2013). PENGARUH PENEMPATAN DAN BEBAN KERJA TERHADAP. Jurnal Manajemen, 67-77.

Ardana. (2012). Manajemen Sumberdaya Manusia. Yogyakarta: Graha Ilmu. 
Arianto, D. A. (2013). PENGARUH KEDISIPLINAN, LINGKUNGAN KERJA DAN BUDAYA KERJA TERHADAP. Jurnal Economia, Volume 9, Nomor 2, Oktober 2013, 191-200.

Azikin, S. S. (2014). Pengaruh Motivasi Dan Kemampuan Kerja Terhadap Prestasi Kerja Pegawai. jurnal paradigma, 64-76.

Diah, N. 2016.Pengaruh Kepuasan Kerja, Lingkungan Kerjadan Loyalitas Kerja Terhadap Organizational Citizenship Behavior (OCB) (Studi Kasus Pada PT. Perwirabhakti Sentrasejatera di Kota Semarang). Jurnal of Management. Vol.2, No.2

Hasibuan, Malayu S.P. 2009. Manajemen Dasar, Pengertian, Dan Masalah. Jakarta: PT Bumi Aksara.

Husein Umar. 2013. Metode Penelitian untuk Skripsi dan Tesis. Jakarta: Rajawali.

Judas, A. (2013). MUTASI DAN PROMOSI JABATAN PENGARUHNYA TERHADAP PRESTASI KERJA PEGAWAI. JURNAL EMBA: JURNAL RISET EKONOMI, MANAJEMEN, BISNIS DAN AKUNTANSI, 1219-1228.

Muayanah, S., Haryono, A. T., \& Wulan, H. S. (2017). PENGARUH KOMPENSASI, LINGKUNGAN KERJA, DAN KOMITMEN ORGANISASI TERHADAP ORGANIZATIONAL CITIZENSHIP BEHAVIOR DENGAN KEPUASAN KERJA SEBAGAI VARIABEL INTERVENING (Studi kasus pada karyawan PT. Fajar Lestari Sejati semarang). Journal of Management.

Noor, M. (2013). Pengaruh Lingkungan Kerja dan Motivasi Kerja Terhadap Prestasi Kerja Pegawai di. Jurnal Paradigma, 441-452.

Nugrah, M. B., \& Surya, I. B. (2016). PENGARUH KOMPENSASI, LINGKUNGAN KERJA DAN PROMOSI JABATAN TERHADAP KEPUASAN KERJA. E-Jurnal Manajemen Unud, Vol. 5, No.1, 59-87.

Saputro, G. A., \& Fathoni, A. (2017). ANALISIS PENGARUH (HUMAN RELATION / HUBUNGAN ANTAR MANUSIA) DAN KONDISI. Jurnal Riset Bisnis Indonesia Vol.2, No.2, Juli, 181-198.

Sedarmayanti.2011, Manajemen Sumber Daya Manusia, Reformasi Birokrasi dan Manajemen Pegawai Negeri Sipil (Cetakan Kelima). Bandung: PT. Efika Aditama

Silalahi, B. P. (2014). Pengaruh Motivasi, Pengawasan dan Disiplin Kerja Terhadap Prestasi Kerja. Jurnal Bisnis dan.

Sofyan, D. K. (2013). Pengaruh Lingkungan Kerja Terhadap Kinerja Kerja Pegawai BAPPEDA. Malikussaleh Industrial Engineering Journal, 18-23.

Utami, H. S. (2013). Pengaruh Iklim Organisasi terhadap Prestasi Kerja Pegawai Dinas Perindustrian. paradigma, 277-289.

wenten, w. (2013). pengaruh insetif finansial terhadap prestasi kerja karyawan pada hotel prawita di Kuta Kabupaten Badung Bali . Widyasrama, 83-88.

Yugusna, I., Fathoni, A., \& Haryono, A. T. (2016). PENGARUH GAYA KEPEMIMPINAN DEMOKRATIS DAN LINGKUNGAN KERJA TERHADAP KINERJA DAN KEDISIPLINAN KARYAWAN (Studi Empiris Pada Perusahaan SPBU 44.501.29 Randu Garut Semarang). Journal Of Management, Volume 2 No.2 Maret 2016. 